\title{
DILEMA AGRARIA PESISIR (Studi Kasus Masyarakat Pesisir Dusun Ujung Genteng Kabupaten Sukabumi)
}

\author{
Coastal Agrarian Problem \\ (Case Study of Coastal Communities Dusun Ujung Genteng and Sukabumi)
}

\author{
Fahrunnisa*), Habibi Azhar, Humayra Secelia Muswar, Helmi Ayuwiradi Miharja, dan A'la Fahmi \\ Program Studi Sosiologi Pedesaan Fakultas Ekologi Manusia, Sekolah Pascasarjana IPB \\ *Email: fahrun.nisa48@gmail.com
}

\begin{abstract}
Fishermen is the main profession of Dusun Ujung Genteng, where the composition of livelihood $80 \%$ fishermen and the rest are civil servants, traders, and entrepreneurs. But in other seasons can change their profession as well as fishermen. Typology beach of Dusun Ujung Genteng are shaped bay makes these waters have more silt than the south coast of the island of Java. The Salinity in these waters are likely to be low and there are many coral reefs make Fish Layur (Trichiurus leputurus) is found in this region. Layur like a gold fish for the fishing of Dusun Ujung Genteng. The high demand for fish Layur from Japan and Korea also increasing economic value of these commodities. Fish Layur able to sell at higher prices rather than other fish. Neighborhoods of fishermen sometimes be things that are often overlooked. Dusun Ujung Genteng has an area of 89 acres to the entire reach, but all the disputed land. Occurs mutual claims between the parties Atang Sanjaya Air Force air base, local community, and prospective policies regarding ecotourism coastal areas. This paper points out that the problems that occur in coastal communities are not only concentrated on marine issues. Region of residence and economic activities of the people residing in coastal areas (not marine) also has friction.
\end{abstract}

Keywords: agrarian problem, coastal areas, communities, dusun ujung genteng, fishermen.

\begin{abstract}
ABSTRAK
Nelayan adalah profesi utama di Dusun Ujung Genteng, di mana komposisi mata pencaharian nelayan sebesar $80 \%$ dan sisanya adalah PNS, pedagang, dan pengusaha. Tapi di musim lainnya, profesi mereka dapat berubah begitu juga dengan nelayan. Tipologi pantai Dusun Ujung Genteng yang berbentuk teluk membuat perairan ini memiliki lumpur lebih dari pantai selatan pulau Jawa. Salinitas di perairan ini cenderung rendah dan ada banyak terumbu karang sehingga Ikan Layur (Trichiurus leputurus) ditemukan di wilayah ini. Layur sejenis ikan emas banyak dipancing di Dusun Ujung Genteng. Tingginya permintaan Layur ikan dari Jepang dan Korea juga meningkatkan nilai ekonomi komoditas ini. Ikan Layur mampu terjual dengan harga yang lebih tinggi daripada ikan lainnya. Lingkungan nelayan terkadang menjadi hal yang sering diabaikan. Dusun Ujung Genteng memiliki luas 89 hektare untuk seluruh jangkauan, tetapi semuanya tanah sengketa. Terjadi saling klaim antara pihak Atang Sanjaya Angkatan Udara pangkalan udara, masyarakat setempat, dan calon kebijakan mengenai wilayah pesisir ekowisata. Makalah ini menunjukkan bahwa masalah yang terjadi di masyarakat pesisir tidak hanya terkonsentrasi pada isu-isu kelautan. Wilayah tempat tinggal dan kegiatan ekonomi masyarakat yang berada di wilayah pesisir (bukan maritim) juga memiliki gesekan.
\end{abstract}

Kata kunci: daerah pesisir, dusun Ujung Genteng, masalah agraria, masyarakat, nelayan.

\section{PENDAHULUAN}

\section{Latar Belakang}

Masyarakat merupakan pengorganisasian sosial atau interaksi sosial yang terpola, berlangsung untuk memenuhi kebutuhan dasar anggota-anggotanya baik di bidang ekonomi, sosial, budaya, pendidikan maupun bidang politik (Titik Sumarti, 2003). Lebih lanjut dijabarkan Satria (2004) dalam Muswar (2011), masyarakat pesisir adalah sekumpulan masyarakat yang hidup bersamasama mendiami wilayah pesisir membentuk dan memiliki kebudayaan yang khas yang terkait dengan ketergantungannya pada pemanfaatan sumberdaya 
pesisir. Aktivitas ekonomi dominan yang digeluti warga Dusun Ujung Genteng tidak jauh dari ekosistem laut yang mendukung mereka. Nelayan merupakan profesi utama masyarakat Dusun Ujung Genteng, dimana komposisi mata pencaharian penduduk $80 \%$ berprofesi sebagai nelayan dan selebihnya adalah PNS, Pedagang, dan Pengusaha. Tetapi pada musim tertentu dapat beralih profesi juga sebagai nelayan.

Dusun Ujung Genteng, berdasarkan letak geografisnya berada pada bibir pantai selatan pulau Jawa yang berbatasan langsung dengan samudera Hindia. Letaknya yang demikian strategis membuat wilayah ini memiliki potensi pembangunan berbasis maritim (Maritime Based Development) yang kuat. Tipologi pantai Dusun Ujung Genteng yang berbentuk teluk membuat perairan ini memiliki endapan lumpur yang lebih dibandingkan pesisir pantai selatan pulau Jawa. Meskipun begitu, laut yang bersifat open access tidak sepenuhnya dapat dimanfaatkan secara setara oleh masyarakat. Tidak hanya itu, darat yang merupakan bagian dari pesisir Dusun Ujung Genteng ini juga mengalami masalah pelik atas status kepemilikan lahan masyarakat. Dimana sengketa lahan berkelanjutan terjadi antara masayarakat dan negara.

\section{Tujuan}

Tulisan ini akan mengutarakan bahwa permasalahan yang terjadi pada masyarakat pesisir tidak hanya terkonsentrasi pada masalah laut. Wilayah tempat tinggal dan aktivitas perekonomian masyarakat yang berada pada pesisir pantai (bukan laut) juga memiliki pergesekan. Perlu memikirkan kembali definisi yang jelas antara nelayan dan masyarakat pesisir, dimana nelayan adalah salah satu profesi dari masyarakat pesisir. Hal ini menanggapi terjadinya tumpang tindih makna yang belakangan sering terjadi antara nelayan dan masyarakat pesisir. Terjadinya konflik antara masyarakat dan negara merupakan bentuk dari konstelasi kebijakan yang tumpang tindih dan tidak memihak. Wawancara mendalam, metode triangulasi, dan observasi lapangan menjadi kekuatan penelitian kualitatif ini.

\section{Kerangka Teori}

Ribot dan peluso dalam jurnal A Theory of Access mendifinisikan akses sebagai kemampuan untuk memperoleh manfaat dari sesuatu: termasuk objek material, individu, institusi dan simbol-simbol. Oleh karenanya akses mengandung makna "sekumpulan kekuasaan/a bundle of right). Kekuasaan itu sendiri diartikan sebagai sesuatu yang terdiri dari elemen-elemen material, budaya, dan ekonomi-politik yang terhimpun dan membentuk "bundel kekuasaan" dan jaringan kepentingan/web of power yang kemudian menjadi penentu akses. Bundel kekuasaan dan jaringan kepentingan ini berjalan melalui mekanisme, proses, dan relasi sosial yang mempengaruhi kemampuan untuk memperoleh manfaat dari sumber daya.

Lebih jauh Ribot dan Peluso menjelaskan mekanisme terbentuknya kases melalui (1) mekanisme rights based access (berbasis hak) yang ditetapkan melalui ketetapan hukum, adat, dan konvensi, (2) mekanisme structural and relational access (akses relasional dan struktural) yang dikarenakan adanya teknologi, tenaga kerja, pengetahuan, wewenang, identitias, dan hubungan sosial. Dengan konsep akses, dapat dilihat siapa yang secara nyata mendapatkan keuntungan, serta melalui proses apa mereka mendapatkannya.

\section{AKSES}

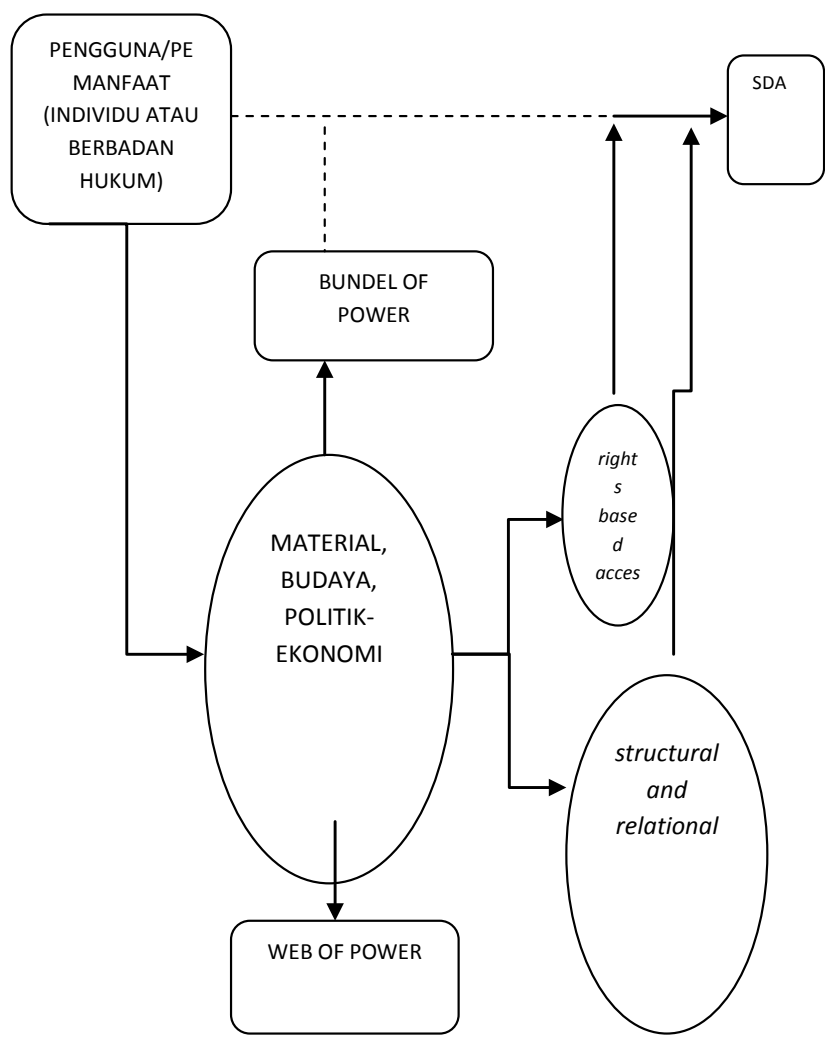

\section{Gambar 1 Teori Akses}

Dusun Ujung Genteng yang merupakan wilayah pesisir di bagian selatan Provinsi Jawa Barat, secara tidak langsung memiliki permasalahan baik di laut maupun di darat. Di wilayah laut sering kali terjadi kompetisi terjadi antara nelayan pemilik dan nelayan buruh, yang disebabkan perbedaan akses di wilayah tangkap. Nelayan pemilik besar dapat mengakses hingga ke tengah laut dan mendapatkan hasil serta jenis ikan yang relatif banyak. Karena memiliki material berupa kapal, teknologi berupa alat-alat tangkap yang memadai, ekonomi yang mapan sehingga mampu membiayai keseluruhan kebutuhan pada saat melaut. Sementara nelayan pemilik kecil hanya mampu melakukan penangkapan di wilayah yang tidak terlalu jauh dari tepi laut karena material, ekonomi maupun teknologi yang dimiliki lebih rendah dibandingkan dengan nelayan pemilik besar. Lebih dari itu, buruh nelayan entah nelayan mandiri maupun nelayan buruh pengikut juga tidak mampu memanfaatkan hasil laut untuk penopang ekonomi meskipun laut merupakan sumber daya yang dimiliki bersama. Hal ini disebabkan nelayan buruh ini sangat kurang bahkan tidak memiliki material, ekonomi, teknologi seperti yang dimiliki nelayan pemilik. Nelayan buruh hanya mengandalkan pengetahuan atau budaya melaut yang dimilikinya. Permasalahan yang dihadapai masyarakat Ujung 
Genteng tidak sebatas terjadi di laut, di darat masyarakat berkonflik dengan Negara yang dalam hal ini diwakili pihak militer. Konfik ini muncul akibat saling klaim masyarakat Ujung Genteng dan militer atas lahan yang ditempati oleh masyarakat Ujung Genteng saat ini. Meskipun masyarakat telah memiliki sertifikat atas lahan tersebut, pada kenyataannya masyarakat belum mampu memanfaatkannya. Hal ini disebabkan militer memiliki kumpulan kekuatan baik itu berupa politik maupun teknologi yang lebih dibandingkan masyarakat. Sehingga melalui kumpulan kekuasaan tersebut militer mampu mengontrol lahan yang ada di Ujung Genteng.

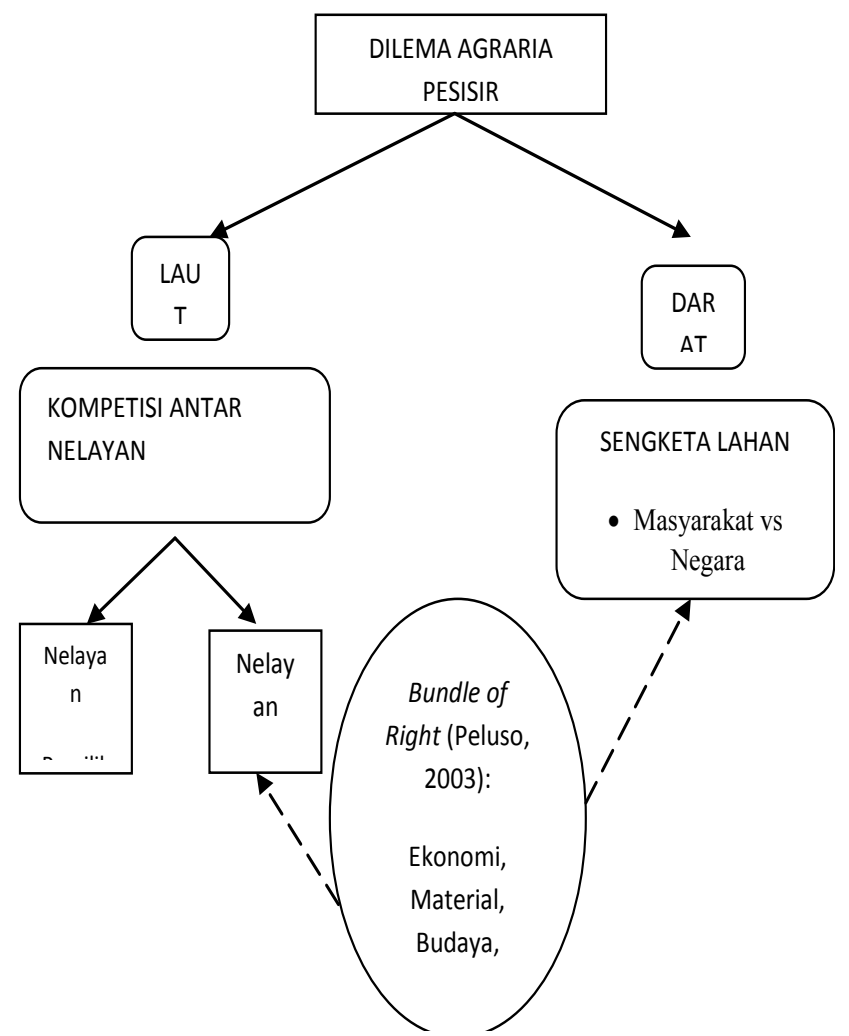

Gambar 2 Alur Pikir Penelitian

\section{PEMBAHASAN}

\section{Laut: Kompetisi Antar Nelayan}

Menurut Ditjen Perikanan Tangkap Kementrian Kelautan dan Perikanan (2007) nelayan adalah orang yang aktif melakukan pekerjaan dalam operasi penangkapan ikan atau binatang air lainnya atau tanaman air. Jika dilihat dari status penguasaan kapital, nelayan dibagi menjadi nelayan pemilik dan nelayan buruh. Nelayan pemilik memiliki sarana perlengkapan sementara nelayan buruh adalah orang yang menjual jasa tenaga sebagai penangkap ikan di laut (Satria 2002). Merujuk pada pola penguasaan kapital tersebut, maka kategori nelayan di Dusun Ujung Genteng juga terbagi atas nelayan yang memiliki kapal dan tidak memiliki kapal. Akan tetapi , nelayan Ujung Genteng juga memiliki kekhasan, dimana nelayan pemilik terbagi lagi menjadi dua kategori yaitu nelayan pemilik besar dan nelayan pemilik kecil. Sementara nelayan buruh terdiri dari nelayan buruh mandiri dan nelayan buruh pengikut.
Laut merupakan sumber daya yang bersifat common resources, akan tetapi tidak semua nelayan memiliki kemampuan yang sama dalam memanfaatkan hasil laut. Perbedaan kemampuan tersebut terletak pada bundel of power yang dimiliki oleh seseorang/kelompok (Ribot and Peluso). Dimana bundle of power tersebut dibentuk oleh material, budaya, ekonomi, politik, maupun teknologi. ${ }^{1}$ Oleh karena itu, kepemilikan atas sarana maupun perlengkapan tangkap yang digunakan secara tidak langsung mempengaruhi kemampuan maupun kesempatan para nelayan untuk memanfaatkan hasil laut.

Di Dusun Ujung Genteng, nelayan pemilik memiliki kemampuan yang lebih besar dibandingkan nelayan buruh karena memiliki material berupa kapal, kemampuan ekonomi untuk membiayai proses melaut, teknologi tangkapan yang memadai serta jaringan pasar yang lebih luas. Akan tetapi jika dibandingkan antara nelayan pemilik kecil dan pemilik besar, maka nelayan pemilik besar memiliki kemampuan untuk mendapatkan hasil tangkapan yang melimpah. Nelayan pemilik besar adalah yang memiliki kapal besar dengan dimensi lebih dari 3 meter dan mampu menampung 5-10 orang. Sementara nelayan pemiliki dengan perahu kecil adalah yang berukuran 1,25 meter dan panjang 8-10 meter serta mampu menampung 2-5 orang. Kemudian hasil tangkapan nelayan pemilik besar dijual secara langsung ke eksportir yang berada di Pelabuhan Ratu dan Jakarta. Disamping itu juga, pemilik modal (perahu, uang, dll) juga merupakan pengepul hasil tangkapan. Adapun jenis tangkapan nelayan besar diantaranya ikan Cakalang, ikan Tuna, ikan Marlin, bahkan ikan Pari. Jenis ikan Pelagis tersebut biasa didapat di tengah laut yang cukup jauh di bibir pantai. Nelayan pemilik kecil biasanya menjual hasil tangkapan ke pemilik modal (perahu, materi,dll). Wilayah tangkap nelayan ini cenderung ke wilayah bibir pantai tidak sampai ke tengah laut. Adapun hasil tangkapan diantaranya Ikan Layur, ikan Cakalang (kadang-kadang), Tongkol Batik dan Tongkol Abu-Abu.

Nelayan buruh mandiri di Dusun Ujung genteng tidak memiliki kapal, namun mereka berusaha mandiri dengan cara meminjam kapal berukuran menengah dengan pola penangkapan maupun hasil sama dengan nelayan pemilik kecil. Perbedaan hanyalah pada status kepemilikan kapal saja. Sementara nelayan buruh pengikut yang hanya ngikut nelayan menengah atau nelayan besar. Upah yang diberikan sebesar Rp 1000/kg dari ikan hasil tangkapan. Oleh sebab itu, nelayan di Dusun Ujung Genteng memiliki dua klasifikasi yang setiap klasifikasi memiliki dua ketegori. Klasifikasi maupun kategori tersebut didasari atas dari kepemilikan, ukuran perahu, wilayah melaut, jenis ikan, dan pembeli dari hasil tangkapan yang akan dijelaskan tabel di bawah.

Adanya klasifikasi yang kemudian terkategori lagi dalam status nelayan Ujung Genteng, dikarenakan tidak semua nelayan memiliki kesadaran yang sama dalam hal kepemilikan modal dan keberanian untuk mengambil resiko dan menjadi mandiri. Posisi nelayan buruh pengikut merupakan pilihan yang dipilih secara sadar oleh nelayan dengan pertimbangan ketika nelayan harus melakukan aktivitas penangkapan ikan dengan kapal sendiri mereka harus mengeluarkan modal. Pada dasarnya nelayan kecil pengikut telah diorganisir untuk kemudian mendapatkan bantuan kapal sebagai modal utama. Namun kenyataannya 
nelayan ini lebih memilih menjual kembali kapal tersebut dari pada memanfaatkannya. Tidak adanya modal ternyata bukan kendala utama yang dihadapi nelayan, akan tetapi lebih pada ketidak mampuan dalam me-managemen usaha perikanan tangkap menjadi salah satu alasan utama nelayan memilih dan nyaman sebagai nelayan buruh pengikuts. Nelayan buruh mandiri dan nelayan buruh pengikut merupakan dua tipe nelayan yang menjadi mayoritas di daerah ini.

Tabel 1. Klasifikasi Nelayan di Dusun Ujung Genteng

\begin{tabular}{|c|c|c|c|c|}
\hline $\begin{array}{l}\text { Aspek } \\
\text { P e m - } \\
\text { beda }\end{array}$ & $\begin{array}{l}\text { Nelayan } \\
\text { Pemilik } \\
\text { Besar }\end{array}$ & $\begin{array}{l}\text { Nelayan } \\
\text { Pemilik } \\
\text { Kecil }\end{array}$ & $\begin{array}{l}\text { Nelay a n } \\
\text { Buruh } \\
\text { Mandiri }\end{array}$ & $\begin{array}{l}\text { N e - } \\
\text { layan } \\
\text { Buruh } \\
\text { Pengi- } \\
\text { kut }\end{array}$ \\
\hline $\begin{array}{l}\text { K e p e - } \\
\text { milikan } \\
\text { Perahu }\end{array}$ & $\begin{array}{l}\text { M i l i k } \\
\text { sendiri }\end{array}$ & $\begin{array}{l}\text { M i l i k } \\
\text { sendiri }\end{array}$ & $\begin{array}{l}\text { Me min - } \\
\text { jam dari } \\
\text { Bos }\end{array}$ & $\begin{array}{l}\mathrm{T} \text { i d a k } \\
\mathrm{M} \mathrm{e} \mathrm{m} \mathrm{i-} \\
\text { liki Ka- } \\
\text { pal }\end{array}$ \\
\hline $\begin{array}{l}\text { Ukuran } \\
\text { Perahu }\end{array}$ & $\begin{array}{l}\text { Lebih dari } \\
3 \text { meter, } \\
\text { m a m p u } \\
\text { m e } \mathrm{n} \text { a m - } \\
\text { pung } 5-10 \\
\text { orang. }\end{array}$ & $\begin{array}{l}\mathrm{L} \text { e b a } \mathrm{r} \\
1,25 \text { me- } \\
\text { ter dan } \\
\text { p an ja } \mathrm{n} \\
8-10 \text { me- } \\
\text { ter serta } \\
\mathrm{m} \text { a m p u } \\
\text { m e n a m - } \\
\text { pung 2-5 } \\
\text { orang. }\end{array}$ & $\begin{array}{l}1 \mathrm{e} \mathrm{b} \text { a } \mathrm{r} \\
1,25 \text { me- } \\
\text { ter dan } \\
\text { panj an } \mathrm{g} \\
8-10 \\
\text { meter sert } \\
\text { m a m p u } \\
\text { m e n a m - } \\
\text { pung 2-5 } \\
\text { orang. }\end{array}$ & - \\
\hline $\begin{array}{l}\text { Wilayah } \\
\text { Melaut }\end{array}$ & $\begin{array}{l}\text { B e r a d a } \\
\text { ditengah } \\
\text { laut. }\end{array}$ & $\begin{array}{l}\text { Wilayah } \\
\text { bibir pan- } \\
\text { tai tidak } \\
\text { s a m p a } \\
\text { ke tengah } \\
\text { laut. }\end{array}$ & $\begin{array}{l}\text { Wilayah } \\
\text { bibir } \\
\text { pantai ti- } \\
\text { dak sam- } \\
\text { pai ke } \\
\text { te n g a h } \\
\text { laut. }\end{array}$ & - \\
\hline $\begin{array}{l}\text { J e n i s } \\
\text { Ikan }\end{array}$ & $\begin{array}{l}\text { I } \mathrm{k} \text { a n } \\
\text { Cakalang, } \\
\text { Ikan Tuna, } \\
\text { Ikan Mar- } \\
\text { lin, bah- } \\
\text { kan Ikan } \\
\text { Pari. }\end{array}$ & $\begin{array}{l}\text { Ikan La- } \\
\text { yur, Ikan } \\
\text { Cakalang } \\
\text { (kadang- } \\
\text { kadang), } \\
\text { Tongkol } \\
\text { Batik dan } \\
\text { Tongkol } \\
\text { Abu-abu. }\end{array}$ & $\begin{array}{l}\text { Ikan La- } \\
\text { yur, Ikan } \\
\text { Cakalang } \\
\text { (kadang- } \\
\text { kadang), } \\
\text { Tongkol } \\
\text { Batik dan } \\
\text { Tongko } \\
\text { Abu-abu. }\end{array}$ & - \\
\hline $\begin{array}{l}\text { Pembeli } \\
\text { H a s i } 1 \\
\text { Tangka- } \\
\text { pan }\end{array}$ & Eksportir & $\begin{array}{l}\text { Bos atau } \\
\text { PT }\end{array}$ & $\begin{array}{l}\text { Bos atau } \\
\text { PT }\end{array}$ & - \\
\hline
\end{tabular}

Aktivitas nelayan tentunya tidak lepas dari kondisi alam terutama cuaca. Sama halnaya seperti petani sawah, nelayan juga memiliki musim panen maupun musim paceklik yang jatuh pada bulan Januari hingga Februari. Sementara musim panen dimulai pada awal Maret sampai dengan bulan Agustus. Lepas bulan Agustus sampai akhir tahun, hasil tangkapan kembali mengalami penurunan hingga menuju musim paceklik di bulan Januari. Pada musim paceklik inilah Rumah tangga nelayan mengalami kerentanan, terlebih pada nelayan buruh mandiri dan nelayan buruh pengikut. Hal ini disebabkan tidak banyak yang memiliki mata pencaharian ganda, dan sangat sedikit diantara nelayan yang memiliki investasi ternak, sawah, ataupun kebun. Sesuai yang dikemukakan Jeffrey Sachs (2005) dalam The End of Poverty bahwa kemerosotan rumah tangga diakibatkan oleh di antaranya ketiadaan tabungan dan investasi.

Hasil tangkap para nelayan tidak selamanya melimpah dan keragaman jenis ikan tidak selamanya terus menerus ada. Dalam satu tahun ada banyak jenis ikan yang hanya muncul di bulan tertentu saja.

\section{Tabel 2. Ketersediaan Jenis Ikan di Dusun Ujung Genteng dalam Kalender 1 Tahun 2014}

\begin{tabular}{|l|l|}
\hline Bulan & Jenis ikan \\
\hline Januari & $\begin{array}{l}\text { Tongkol, Cumi, Tenggiri, Lodi, } \\
\text { Kapas, Belida }\end{array}$ \\
\hline Februari & Layur Pancing, Marlin, \\
\hline Maret & Layur Pancing, Marlin \\
\hline April & Layur Pancing, Marlin \\
\hline Mei & Giant Traveling, Marlin \\
\hline Juni & Ikan Kembung,Keong Laut \\
\hline Juli & Ikan Kembung,Keong Laut \\
\hline Agustus & Ikan Kembung, Keong Laut \\
\hline September & Lobster, Kakap \\
\hline Oktober & Lobster, Kakap \\
\hline November & $\begin{array}{l}\text { Layur Jaring, Tenggiri, Lodi, } \\
\text { Udang Cerebung, Kapas, Belida }\end{array}$ \\
\hline Desember & $\begin{array}{l}\text { Layur Jangk, Jaring, } \\
\text { Tenggiri,Lodi, Udang Cerebung, } \\
\text { Kapas, } \\
\text { Belida }\end{array}$ \\
\hline
\end{tabular}

Sumber: Data primer hasil olahan data pengamatan pada nelayan di Dusun Ujung Genteng

Di Dusun Ujung Genteng terdapat Kredit Usaha Bersama (KUB) yang diberikan kepada nelayan dengan sistem kelompok. Kelompok nelayan yang mendapat KUB sedikit mampu melakukan resiliensi dengan adanya kewajiban untuk memiliki simpanan. Bos atau ketua KUB berperan dalam mengatur simpanan tersebut yang didapat dari sisa uang belanja nelayan. Seperti yang dilakukan oleh kelompok nelayan Alam Sejahtera, dimana bos melakukan simpanan yang diambil dari keuntungan bersih. Sebelum ada KUB para nelayan cenderung lebih konsumtif dan tidak mampu menyimpan uangnya ketika dalam masa paceklik. Homogenitas yang terjadi di antara berbagai lapisan kelas nelayan di dusun ini adalah struktur pola nafkah yang hanya mengandalkan Kepala Keluarga sebagai pencari nafkah, sementara istri berperan pasif di rumah.

\section{Darat: Sengketa Lahan}

Persoalan akses juga dihadapi masyarakat Ujung Genteng pada sumber daya agraria pesisir. Terjadi saling klaim hak 
kepemilikan atas lahan yang ditempati masyarakat saat ini dengan Negara. Dalam prosesnya, Negara bahkan tidak segan menggunakan metode yang keras seperti intimidasi, teror bahkan bentrok fisik melalui aparat keamanan dalam kasus ini yaitu militer yang memang menjadi aktor lokal negara yang langsung berhadapan dengan masyarakat Dusun Ujung Genteng. Urutan kejadian konflik agraria di Dusun Ujung Genteng dapat dijelaskan sebagai berikut: kedatangan pihak militer pada tahun 1965, Reclaim pihak militer pada krisis 1998, dan kedatangan pemodal tahun 2009.

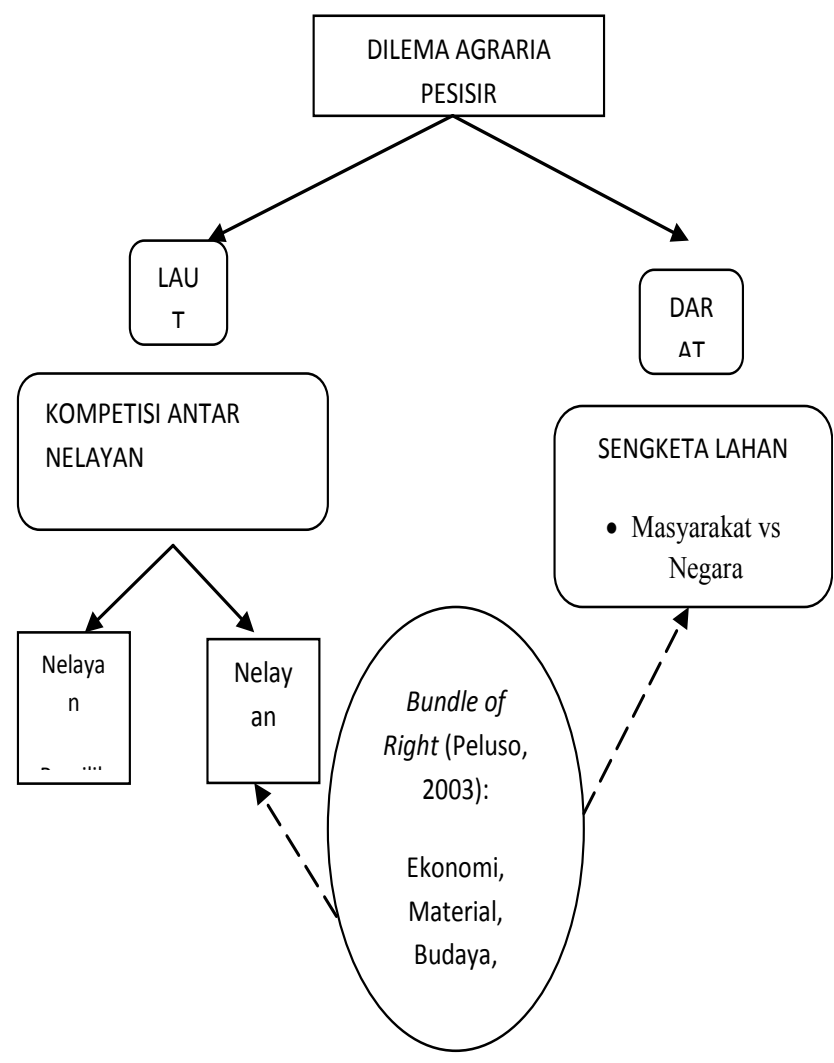

Gambar 3 Sejarah konflik agraria

Pertentangan ini muncul karena Negara menganggap bahwa lahan desa Ujung Genteng merupakan wilayah kekuasaan militer yang berlaku sejak rezim orde baru. Klaim tersebut berdasarkan adanya radar keamanan yang ditempatkan di Dusun Ujung Genteng sejak tahun 1965 dalam rangka melindungi NKRI dilahan seluas 3,5 Ha. Pada saat itu wilayah Desa maupun Dusun Ujung Genteng belum dibentuk dan masih terintegrasi dengan Desa Gunung Batu. Ketika itu kekuasaan militer terlihat juga dengan ditetapkan pemimpin Desa yang berasal dari kalangan militer.

Pertumbuhan penduduk yang terus meningkat secara langsung memengaruhi kuantitas penggunaan/pemanfaatan sumber daya alam, baik yang berada di darat maupun di laut. Akibatnya perpindahan penduduk untuk mencari sumber nafkah baru terus saja berlangsung. Demikian juga dengan penduduk yang berada di Pelabuhan Ratu, Banten dan lokasi-lokasi sekitar untuk mencari wilayah baru dan kemudian menetap di wilayah tersebut. Wilayah inilah yang menjadi cikal-bakal dari Dusun Ujung Genteng. Setelah Dusun Ujung Genteng terbentuk, mulailah diterapkan berbagai macam aturan maupun putusan terkait penyelenggaraan pemerintahan Dusun yang berlaku di Indonesia. Rentang waktu 1945-1998 penguasaan lahan di Dusun Ujung Genteng sudah dimiliki oleh warga sekitar secara De Facto dan De Jure. De Jure, mereka memiliki sertifikat tanah yang dikeluarkan oleh Badan Pertanahan Nasional sejak 1998, sementara De Facto mereka mendiami kawasan itu sejak tahun 1945 (AGRA, 2010).

Memiliki sertifikat resmi atau hak atas lahan bukan berarti penduduk Ujung Genteng memiliki kekuasaan atas tanah tersebut. Karena Negara yang diwakili militer juga mengklaim wilayah Ujung Genteng sebagai wilayah kekuasaan mereka. Saat Indonesia mengalami krisis moneter tahun 1998, pihak militer datang dan kemudian melakukan pengukuran lahan dengan dalih untuk melakukan pengamanan di wilayah tersebut. Padahal pengukuran tersebut untuk mengetahui luas wilayah yang akan diklaim. Adanya klaim hak atas tanah antara warga dengan Negara yang diwakili militer pada akhirnya berujung konflik. Masyarakat kerap kali mendapat intimidasi dari pihak militer. Di satu sisi, warga juga selalu melakukan upaya perlawanan, baik dalam bentuk demonstrasi yang berujung pada baku hantam antara keduanya, dan perlawanan melalui jalur hukum.

Di tengah persoalan masyarakat dengan Negara yang kian memanas, datang pemodal dari kota yang membeli tanah warga. Warga menganggap pemodal dari kota tersebut sebagai pahlawan dari teror dan ancaman Negara yang kerap dilakukan pihak militer kepada masyarakat. Masyarakat rela tanahnya dibeli dengan alasan untuk menghindari kerugian atau kehilangan lahan yang ingin direbut pihak militer yang akan dijadikan landasan udara (LANUD). Terbukti setelah beberapa luas lahan yang telah berpindah tangan ke tangan pemodal, intensitas teror terhadap warga mulai berkurang.

Berdasarkan kerangka sejarah di atas dapat di-identifikasi beberapa hak kepemilikan yang dimiliki Negara yang diwakili pihak militer maupun masyarakat Dusun Ujung Genteng. Hal ini merujuk pada Ostrom dan Schlager (1996) dalam Satria (2006) dan Ostorm dan Hess (2007), bahwa hak atas sumberdaya milik bersama dapat bertipe access right sampai alleniation right. Salah satu bentuk hak kepemilikan sumberdaya alam adalah hak kepemilikan komunal (Berkes (1989) dalam Adhuri (2004)). Hak kepemilikan ini memiliki peran penting dalam keseharian komunitas tersebut, antara lain:

1) Memastikan keamanan mata pencaharian, dengan memastikan setiap anggota dari komunitas dapat memenuhi kebutuhan dasar dengan memanfaatkan hak akses atas sumberdaya alam yang vital.

2) Resolusi konflik, Berkes percaya bahwa hak kepemilikan bersama (komunitas) membuktikan bahwa adanya mekanisme yang adil dalam pemanfaatan sumberdaya alam dapat meminimalisir kemungkinan perselisihan atau konflik.

3) Hak kepemilikan bersama mengikat para anggota komunitas menjadi satu unit yang kompak dan membentuk keanggotaan serta kontrol atas sumberdaya bersama untuk memfasilitasi kerja tim dan koorperasi.

4) Hak kepemilikan bersama bersifat konservasionis karena biasanya berdasarkan pada prinsip ambil sesuai kebutuhan. 
Hak kepemilikan bersama dikatakan dapat membantu menjaga keberlanjutan ekologi, dan dengan pengelolaan bersama ini sering kali menggabungkan praktek ritual yang disinkronisasikan dengan siklus alam. Ostrom et.al (1999) memaparkan mengenai tipe hak kepemilikan atas sumberdaya bersama.

\section{Tabel 3. Hak Kepemilikan dan Karakteristiknya}

\begin{tabular}{ll}
\hline Hak Kepemilikan & Karakteristik \\
\hline $\begin{array}{l}\text { Open Access (Akses } \\
\text { Terbuka) }\end{array}$ & $\begin{array}{l}\text { Tidak ada yang memegang hak } \\
\text { kepemilikan pada tipe kepemi- } \\
\text { likan ini }\end{array}$ \\
$\begin{array}{l}\text { Kepemilikan Kelom- } \\
\text { pok }\end{array}$ & $\begin{array}{l}\text { Hak kepemilikan sumberdaya } \\
\text { dipegang oleh sekelompok } \\
\text { pengguna yang dapat mengek- } \\
\text { sklusi orang lain }\end{array}$ \\
Kepemilikan Pribadi & $\begin{array}{l}\text { Hak kepemilikan sumberdaya } \\
\text { dipegang oleh individu atau pe- } \\
\text { rusahaan yang dapat mengek- } \\
\text { slusi orang lain }\end{array}$ \\
Kepemilikan Pemerin- & $\begin{array}{l}\text { Hak kepemilikan sumberdaya } \\
\text { dipegang oleh pemerintah yang }\end{array}$ \\
dah & dapat mengeksklusi pihak lain
\end{tabular}

Dari beberapa hak yang dijelaskan oleh Ostrom, Negara mempunyai hak yang lebih lengkap dengan mampu untuk mengaleniasi masyarakat Dusun Ujung Genteng untuk melarang mendirikan bangunan. Seperti yang dialami oleh A pada waktu ingin memperluas teras halaman rumahnya kemudian pihak militer datang meminta "jatah". Hal yang lebih parah yang dialami oleh I pada tahun 2012 ketika proses pembangunan rumah yang hampir rampung, militer langsung merobohkannya tanpa memberikan ganti rugi sama sekali kepada I. Teror yang dilakukan oleh aparat keamanan negara ini tidak berhenti pada tataran rumah tangga saja tetapi juga pada fasilitas umum yang statusnya sangat jelas milik Negara yaitu Tempat Pelelangan Ikan (TPI) yang berada di Desa Ujung Genteng. Dalam hal ini masyarakat pesisir hanya memiliki hak eksklusi. Dimana dengan hak ini masyarakat kemudian menjual tanah yang mereka miliki kepada pengusaha yang berada di luar dusun. Secara sosiologis apa yang dilakukan oleh masyarakat di Desa Ujung Genteng merupakan siasat rasional untuk menghindari konflik dengan pihak militer dan selain itu juga ingin meminimalisir kerugian dari tanah tersebut jika terjadi perampasan oleh Negara.

Analisa dari bundle of power pun memperlihatkan kesenjangan di antara kedua pihak. Masyarakat yang hanya memiliki kuasa dalam hal budaya seperti kearifan lokal dan kesejarahan bermukim sebelum kemerdekaan melawan negara dengan segenap kuasa politik dan hukum legal-formal serta teknologi modern. Dalam sengketa lahan di Dusun Ujung Genteng, pihak pemerintah selalu mengundang keterlibatan aparat keamanan (militer) untuk mengatasi perlawanan warga yang bersikeras mempertahankan hak atas lahan mereka. Hal ini menimbulkan kekerasan terhadap masyarakat mulai dari perusakan, intimidasi sampai teror. Tetapi pada kondisi terkini, penguasaan lahan di Ujung Genteng menggambarkan munculnya aktor baru dalam penguasaan bundle of power tersebut. Pemodal dari kota dapat mewakili pasar dengan kekuatan ekonomi, politik serta teknologinya yang mampu menjadi lawan sekaligus kawan bagi Negara. Hal ini pula yang menjadi dilema tersendiri bagi keberlanjutan masyarakat pesisir Dusun Ujung Genteng.

\section{KESIMPULAN}

Wilayah pesisir Dusun Ujung Genteng dengan segala potensi wisata dan hasil tangkapan yang bernilai komoditas ekspornya ternyata menyimpan persoalan baik di laut maupun di darat. Di wilayah laut sering kali terjadi kompetisi terjadi antara nelayan pemilik dan nelayan buruh, yang disebabkan perbedaan akses di wilayah tangkap. Sedangkan di darat masyarakat berkonflik dengan Negara yang dalam hal ini diwakili pihak militer. Konfik ini muncul akibat saling klaim masyarakat Ujung Genteng dan militer atas lahan yang ditempati oleh masyarakat saat ini. Meskipun masyarakat telah secara resmi memiliki sertifikat atas lahan tersebut. Analisa bundle of power memperlihatkan kesenjangan di antara kedua pihak. Penjualan lahan kepada pemodal menjadi pilihan dilematis karena pasar dan negara di satu sisi mampu menjadi lawan sementara di sisi lainnya mampu menjadi kawan. Posisi yang tidak menguntungkan bagi masyarakat Dusun Ujung Genteng. Model pengelolaan kawasan berbasis masyarakat menjadi sangat relevan sebagai resolusi konflik dalam kasus ini. Keterlibatan masyarakat yang sering menjadi korban marjinalisasi dari tumpang tindih kebijakan serta ketidakberpihakan Negara yang sering terjadi di sekitar kawasan pesisir seharusnya dilihat sebagai potensi pembangunan kemaritiman yang juga menjadi agenda utama rezim pemerintah kini.

\section{DAFTAR PUSTAKA}

Adhuri, Dedi Supriadi. 2004. "The Incident In Dullah Laut: Marine Tenure and the Politics of Village Leadership in Maluku, Eastern Indonesia".

Jesse C. Ribot dan Peluso, N. 2003. "A Theory of Access". Jurnal Rural Sociology, June 2003, Vol. 68, No. 2.

Muswar, Humayra Secelia. 2011. Dampak Pelabelan Ramah Lingkungan (ecolabeling) terhadap Nelayan Ikan Hias(Kasus: Nelayan Ikan Hias Desa Les, Kec. Tejakula, Kab. Buleleng,Bali). Bogor: Institut Pertanian Bogor. Skripsi. Tidak dipublikasikan.

Laporan Aliansi Gerakan Reforma Agraria (AGRA). 2010. Perampasan Tanah: Sebab, Bentuk dan Akibatnya bagi Kaum Tani [internet]. [diunduh 2015 Februari 16]. Tersedia pada http://farmlandgrab.org/wpcontent/uploads/2010/09/Risalah-ttg-PerampasanTanah_24-Sept-2010.doc

Ostorm, Elinor, et.al. 1999. "Revisiting the Commons: Local Lessons, Global Challenges". Science 284, 278 (1999).

Ostorm, Ellinor dan Charlotte Hess. 2007. "Private and Common Property Rights". Workshop mengenai Political Theory and Policy Analysis, Indiana University. W07-25. Tahun 2007.

Sach, Jeffrey D. 2005. The End of Poverty. New York: The Penguin Press

Satria, Arif. 2002. Pengantar Sosiologi Masyarakat Pesisir. Jakarta: Cesindo. 
2006. "Politics of marine conservation area in Indonesia: from a centralised to a decentralised system". Int. J. Environment and Sustainable Development, Vol. 5, No. 3, 2006.

2006. "Decentralization of Property Right in Marine Fisheries: Indonesia Perspective". Tidak dipublikasikan. 
